\title{
EXAMINATION OF PERCUTANEOUS APPLICATION IN A 26-WEEK CARCINOGENICITY TEST IN CB6F1-TG rasH2 MICE
}

\author{
Koji URANO ${ }^{1}$, Shuzo SUZUKI ${ }^{1}$, Kazuhiko MACHIDA ${ }^{1}$, Natsuko EGUCHI ${ }^{1}$, Nobuko SAWA ${ }^{1}$, \\ Koji KIKUCHI ${ }^{2}$, Yuji HATTORI ${ }^{1}$ and Toshimi USUI ${ }^{1}$ \\ ${ }^{1}$ Central Institute for Experimental Animals, 1430 Nogawa, Miyamae, Kawasaki 216-0001, Japan \\ ${ }^{2} J A C$, Inc., 1-2-7 Higashiyama, Meguro, Tokyo 153-0043, Japan
}

(Received April 23, 2007; Accepted July 10, 2007)

\begin{abstract}
We examined the possibility of expanding applications of ras $\mathrm{H} 2$ mice, which are genetically manipulated mice for short-term carcinogenicity tests, to percutaneous application. A 26-week short-term carcinogenicity study was performed on a total of 300 mice including 75 male and female ras $\mathrm{H} 2$ mice each, and 75 male and female non- $\mathrm{Tg}$ mice each from the same litter as the ras $\mathrm{H} 2$ mice divided into untreated group, an ethanol group, a white Vaseline group, an acetone group, and a phorbol 12-myristate 13-acetate (TPA) group. Only shaving of dorsal skin was performed on the untreated mice. As a positive control, TPA was administered percutaneously at a dose of $2.5 \mu \mathrm{g} / \mathrm{kg}$ and 3 times/week for 26 weeks based on the protocol for Tg.AC mice in the ILSI/HESI international validation study. In the ethanol, white Vaseline, and acetone groups, no tumorous changes were observed on the skin at the administration site. In the TPA group, nodular changes at the administration site were observed from seven weeks after the start of administration in $\mathrm{ras} \mathrm{H} 2$ mice, and the incidence in males and females was $50.0 \%$ (7/14) and 53.3\% (8/15), respectively. In a pathological examination, nodules in $21.4 \%(3 / 14)$ of males and $46.7 \%(7 / 15)$ of females were diagnosed as skin papilloma or keratoacanthoma, and the rest as squamous cell hyperplasia. In the non-Tg mice, no nodules or tumorigenic changes were observed at the administration site. These findings show that percutaneous application in ras $\mathrm{H} 2$ mice is possible in 26week carcinogenicity tests.
\end{abstract}

KEY WORDS: Carcinogenicity, Percutaneous administration, rasH2 mice, Short-term carcinogenicity test, Transgenic mice

\section{INTRODUCTION}

The $\mathrm{CB} 6 \mathrm{~F} 1-\mathrm{Tg} r a s \mathrm{H} 2$ (rasH2) mouse is a genetically manipulated mouse developed for use in shortterm carcinogenicity tests. It has three copies of the cHa-ras gene of human origin inserted in tandem under prototype genome DNA conditions that bind with internal promoters or enhancers (Tamaoki, 2001). The carcinogenicity of this mouse has been investigated in a large number of in-house certification studies (Yamamoto et al., 1998) and the ILISI/HESI International Collaborative Certification Study (Usui et al., 2001) and the mouse has been found to respond appropriately to both genotoxic and nongenotoxic carcinogens. Based on these results, regulatory authorities in the EU, Japan and the USA approved this mouse as an animal for use in short-term carcinogenicity tests to replace long-term carcinogenicity tests (MacDonald et al., 2004). However, they did not approve use of this strain for percutaneous application, although a 26week carcinogenicity test on 4-vinyl-1-cyclohexene diepoxide, a mutagenic carcinogen (National Toxicology Program, 1989), by percutaneous administration had already been performed in the aforesaid in-house certification studies on ras $\mathrm{H} 2$ mice, and skin papilloma/squamous cell carcinoma was observed (Yamamoto et al., 1998).

The Tg.AC mouse is transfected with the v-Haras gene using the $\zeta$ (zeta)-globin gene as an external promoter (Leder et al., 1990). In the International Collaborative Certification Study mentioned above, both oral and percutaneous administration were examined

Correspondence: Toshimi USUI (E-mail: usui@ciea.or.jp) 
(Eastin et al., 2001), and applications for drugs for percutaneous use only are accepted by the regulatory authorities in the Western countries but not in Japan (MacDonald et al., 2004). These Tg.AC mice are reported to include both homozygous mice and heterozygous mice, but the palindrome phenomenon is apt to occur because external promoters and enhancers are bound to more than 40 copies of the transgene, and gene stability is not reliable, resulting in non-responders among the animals (Honchel et al., 2001; Thompson et al., 1998). Because the skin repair reaction induces expression of the transgene (Cannon et al., 1997), any accidental trauma during the study will induce carcinogenesis, which can affect the study results (Weaver et al., 1998). Therefore, an alternative model is needed for carcinogenicity tests on percutaneous drugs.

As a first step for expanding the usefulness of ras $\mathrm{H} 2$ mice, their possible application in carcinogenicity tests on drugs for percutaneous administration has been considered. Twenty-six-week carcinogenicity tests by percutaneous administration of phorbol 12myristate 13-acetate and acetone used as a positive control agent and a negative control agent, respectively, for Tg.AC mice in the ILSI/HESI International Collaborative Certification Study (Eastin et al., 2001) were performed to examine this possibility. Ethanol and white Vaseline widely used as solvents of drugs for percutaneous use were also investigated in this study.

\section{MATERIALS AND METHODS}

The protocol of the present study was reviewed beforehand and approved by the Animal Ethics Committee of the Central Institute for Experimental Animals (CIEA) and all of the animal experiments were performed according to the Ethical Guideline for Animal Experimentation of CIEA.

\section{Animals}

Three hundred-mice in total were used, including 75 males and females each with the human prototype c-Ha-ras gene introduced (Jic: CB6F1-Tgras H2@Jcl, CLEA Japan Inc., Tokyo, Japan; ras $\mathrm{H} 2$ mice hereinafter) and 75 males and females each of ras $\mathrm{H} 2$ mouse littermates without the gene introduced (non-Tg mice). All animals were reared in plastic cages $(190 \times 245 \times$ 130 mm, CLEA Japan Inc., Tokyo, Japan) at two animals per cage in an animal room with temperature controlled at $24 \pm 2{ }^{\circ} \mathrm{C}$, humidity at $60 \pm 15 \%, 12-25$ ventilations/hr and $12 \mathrm{hr}$ of artificial lighting (8:00-20:00) (often accommodated at one to a cage when fighting occurred). Commercial diet (NIH07, CLEA Japan Inc, Tokyo, Japan) was supplied ad libitum and UV radiation sterilized and filtered tap water was supplied $a d$ libitum as drinking water using a water bottle.

\section{Twenty-six week short-term carcinogenicity test 1. Group composition}

The animals were divided into five groups at the start of administration so that there was no difference in mean body weights and the 26-week short-term carcinogenicity test was performed from 6-7 weeks of age. The details of each group were as follows.

\section{1) Untreated group}

The animals of this group underwent depilation on the back every 1-2 weeks using a miniature electric razor (ER333P-G, Matsushita Electric Works, Tokyo, Japan). Administration was not performed.

\section{2) Ethanol group}

The animals underwent depilation on the back by the same method as used with the untreated group. Ethanol (Code No. 051-06135, Wako, Osaka, Japan) was administered percutaneously every day into the backs $\left(2 \mathrm{~cm} \times 2 \mathrm{~cm}=4 \mathrm{~cm}^{2}\right)$ of the mice at a dose of $1 \mathrm{~mL} / \mathrm{kg}$.

\section{3) White Vaseline (Vaseline) group}

The animals underwent depilation on the back by the same method as with the untreated group. White Vaseline (Code No. 224-00165: Wako, Osaka, Japan) was administered percutaneously every day for 26 weeks into the backs $\left(2 \mathrm{~cm} \times 2 \mathrm{~cm}=4 \mathrm{~cm}^{2}\right)$ of the mice. The dosage volume was $10 \mu \mathrm{L} / \mathrm{mouse}$. All mice in this group wore an Elizabeth collar to prevent oral intake by grooming because white Vaseline is an adhesive substance. Just before each administration, the back of each mouse was wiped by cotton soaked in warm water to remove Vaseline applied the day before.

\section{4) Acetone group}

The animals underwent depilation on the back by the same method as with the untreated group. Acetone (Code No. 016-15535; Wako, Osaka, Japan) was administered percutaneously every day for 26 weeks into the backs $\left(2 \mathrm{~cm} \times 2 \mathrm{~cm}=4 \mathrm{~cm}^{2}\right)$ of the mice. The dosage volume was $1 \mathrm{~mL} / \mathrm{kg}$.

\section{5) 12-o-tetradecanoylphorbol-13-acetate (TPA) group}

The animals underwent depilation on the back by the same method as with the untreated group. TPA (Code No. 549-00264; Wako, Osaka, Japan) dissolved at $25 \mu \mathrm{g} / \mathrm{mL}$ in acetone was administered percutaneously three times/week for 26 weeks into the backs $\left(2 \mathrm{~cm} \times 2 \mathrm{~cm}=4 \mathrm{~cm}^{2}\right)$ of the mice. The single dosage volume was $100 \mu \mathrm{L}(2.5 \mu \mathrm{g} /$ animal as TPA $)$. 
Dermal application to $\mathrm{ras} \mathrm{H} 2$ mice.

\section{Clinical findings}

General signs and symptoms were observed daily in all animals just after group formation. In particular, the appearance, number and size of nodules at the administration site were recorded, and then totaled weekly.

\section{Body weight}

The animals were weighed once before start of administration, once a week after start of administration and once on the day of the planned necropsy using an electronic balance (EL-600SA, Shimadzu Corporation, Kyoto, Japan). The most recent data were collected for dead animals and animals undergoing emergency sacrifice.

\section{Pathological examination}

All animals were necropsied on the day after final administration, or at the time of death or emergency sacrifice. Systemic visual observations were performed. The skin (administration site), liver, kidneys, spleen, thymus, lungs, stomach and sites where visual abnormalities were observed were fixed in $10 \%$ neutral buffered formalin. Then hematoxylin-eosin stained specimens were prepared by the usual method and subjected to a histopathologic examination.

\section{Statistical analysis}

Mean body weights were calculated for each gender and each dosing group. An analysis of variance was performed using the $F$ test, and differences from the untreated group were tested by Welch's $t$-test or Student's $t$-test when the $\mathrm{p}$ value of $F$ test was under 0.05 or more than 0.05 , respectively, with $\mathrm{p}<0.05$ taken as significant. For the pathological results, differences in the incidences of each lesion with respect to the untreated group were tested by Fisher's exact probability test with $\mathrm{p}<0.05$ taken as significant. The analyses were conducted using SAS System Release 8.2 and SAS Clinical Package Version 5.0 (SAS Institute, Tokyo, Japan).

\section{RESULTS}

\section{Clinical findings}

In the TPA group of ras $\mathrm{H} 2$ mice, desquamative changes at the administration site were observed from three weeks and two weeks after the start of administration in all males and females, respectively. These changes had stopped by 6-9 weeks after administration in both sexes, but nodules formed on the skin surface at the same site. By the end of this study, the incidence, average multiplicity and mean diameter of these nodules were $50.0 \%$ (7/14), 1.4 nodules/animal (range: 12 nodules/animal) and $3.7 \mathrm{~mm}$ (range: $1-8 \mathrm{~mm}$ ) in males and 53.3\% (8/15), 1.9 nodules/animal (range: 14 nodules/animal) and $6.8 \mathrm{~mm}$ (range: $1-20 \mathrm{~mm}$ ) in females (Fig. 1). Hair loss at the Elizabeth collar site (cervical area) was observed in all mice of both sexes in the Vaseline group, but there were no nodules at this site. No noteworthy changes were found in males and females in the untreated group, ethanol group and ace-

\section{rasH2 Males}

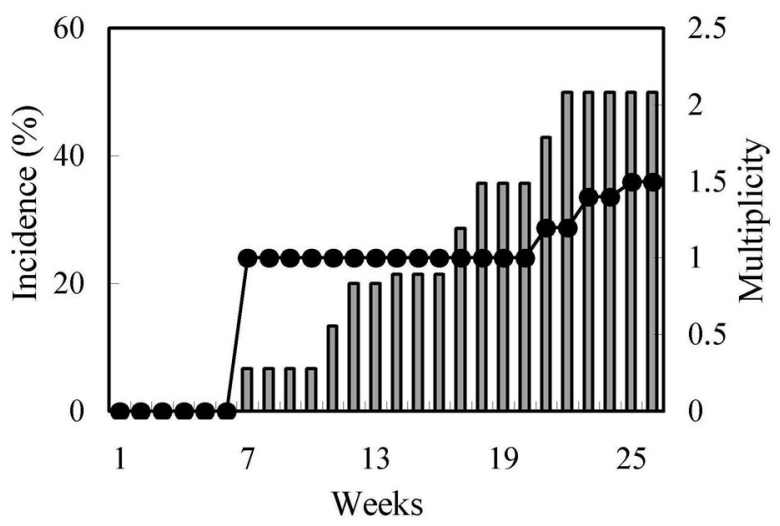

rasH2 Females

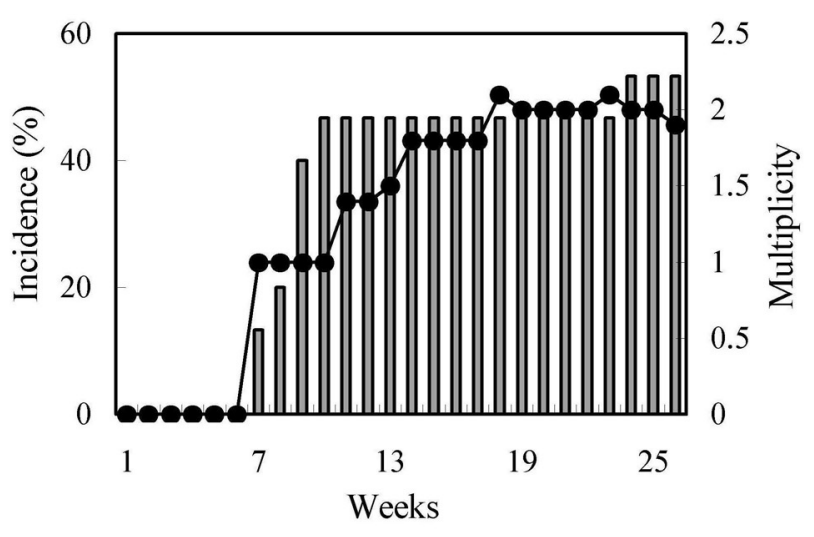

Fig. 1. Incidence and multiplicity of dorsal nodule in TPA applied ras $\mathrm{H} 2$ mice. Incidence (shown by columns with scale on the left) and multiplicity (shown by lines with scale on the right) of dorsal nodule in TPA applied ras $\mathrm{H} 2$ mice. No dorsal nodule was observed in TPA applied non-Tg mice. 
tone group.

In the non-Tg mice, desquamative changes were found at the administration sites at 3-6 weeks and 2-5 weeks after the start of administration in males and females in the TPA group, respectively. However, these changes stopped, and no nodule formation was observed after that. Hair loss at the Elizabeth collar site (cervical area) was observed in all mice of both sexes in the Vaseline group, but nodules were not observed at this site. No noteworthy changes were found in males and females in the untreated group, ethanol group and acetone group.
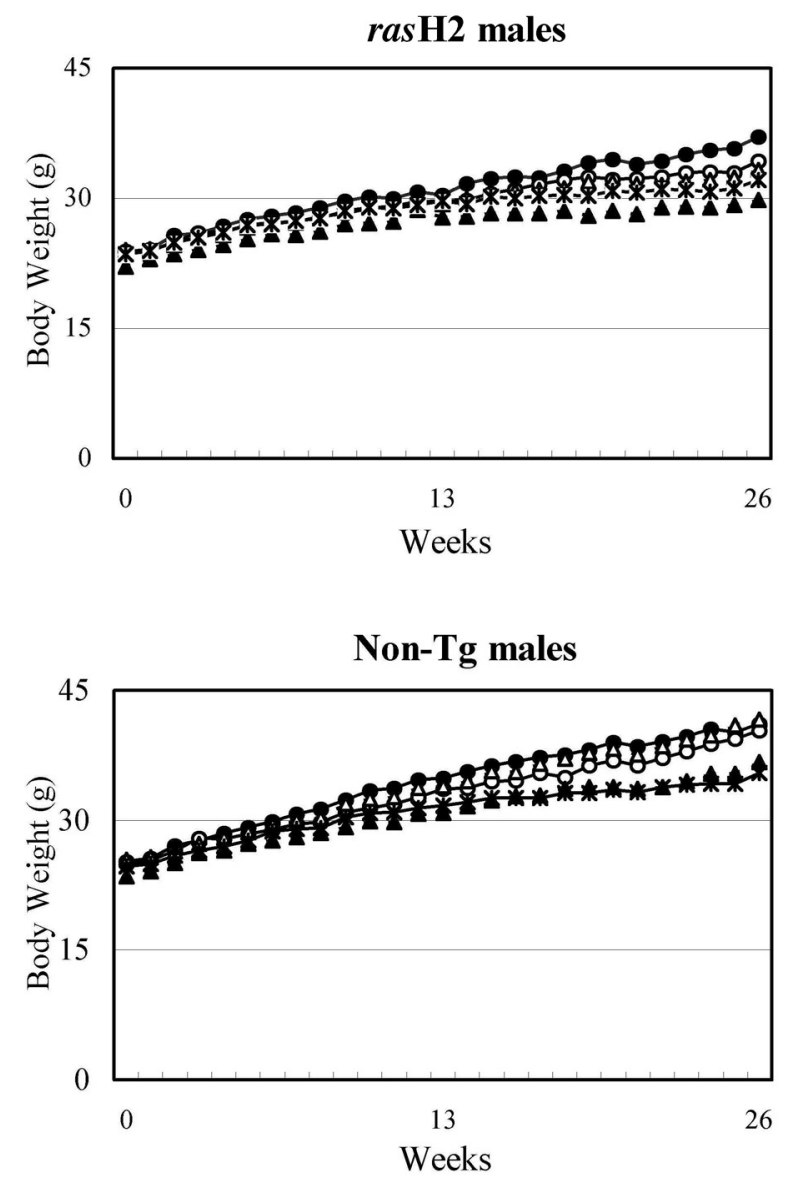

\section{Body weights}

In ras $\mathrm{H} 2$ male mice, inhibition of body weight gain was observed in the Vaseline group just after the start of administration, in the TPA group at nine weeks after administration and in the ethanol and acetone groups in the second half of the study period. In females, none of the groups showed any differences from the untreated group (Fig. 2).

In male non-Tg mice, inhibition of body weight gain was observed just after the start of administration in the Vaseline group and in the TPA group at nine weeks after administration. In females, none of the groups showed any differences from the untreated group (Fig. 2).
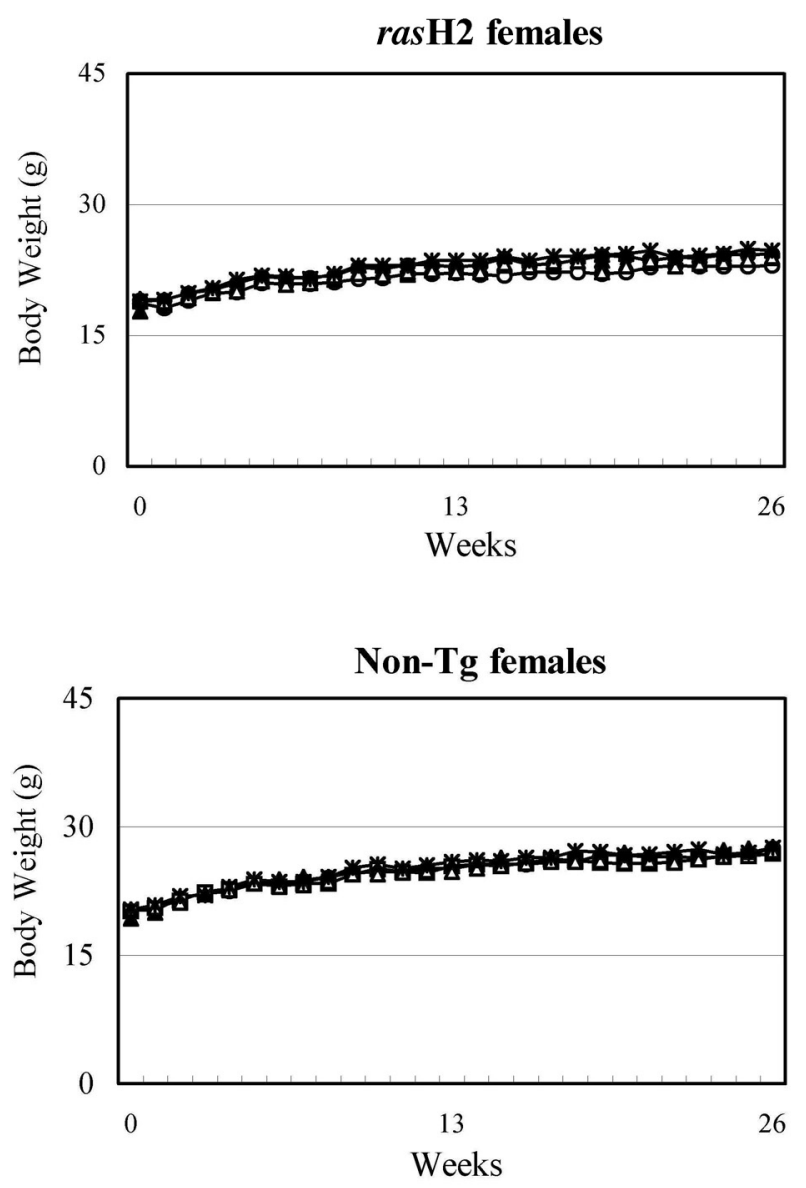

Fig. 2. Body weight changes in rasH2 and non-Tg mice.

$\boldsymbol{\bullet}, \boldsymbol{O}, \boldsymbol{\Delta}, \boldsymbol{\Delta}$, and $\boldsymbol{*}$ : Mean body weight: Untreated group, ethanol group, Vaseline group, acetone group, and TPA group, respectively. Significant differences from untreated group were observed in all dose groups of ras $\mathrm{H} 2$ males, and Vaseline and TPA groups of non-Tg males. No significant defferences from untreated group were observed in any dose groups in both ras $\mathrm{H} 2$ and non- $\mathrm{Tg}$ females. 
Dermal application to $\mathrm{ras} \mathrm{H} 2$ mice.

\section{Pathological examination}

From nodular changes observed in ras $\mathrm{H} 2$ mice in the TPA group, $21.4 \%$ (3/14) of males and $46.7 \%$ (7/15) of females were diagnosed with skin papilloma (Fig. 3) or keratoacanthoma, and the rest with squamous cell hyperplasia. Tumorigenic changes were observed in the spleen, lungs and liver in the ethanol, Vaseline or acetone group, but no significant differences in incidences from the untreated group were shown. Inflammatory cell infiltration, thickening of the epidermis and fibrosis were found at the hair loss sites around the Elizabeth collar in several mice in the Vaseline group, but no neoplastic changes were observed at this site (Table 1-1).

In non- $\mathrm{Tg}$ mice, no tumorigenic changes were found in the TPA group. Lung adenoma was observed in females in the Vaseline group and males in the ethanol group, but no significant differences in incidence
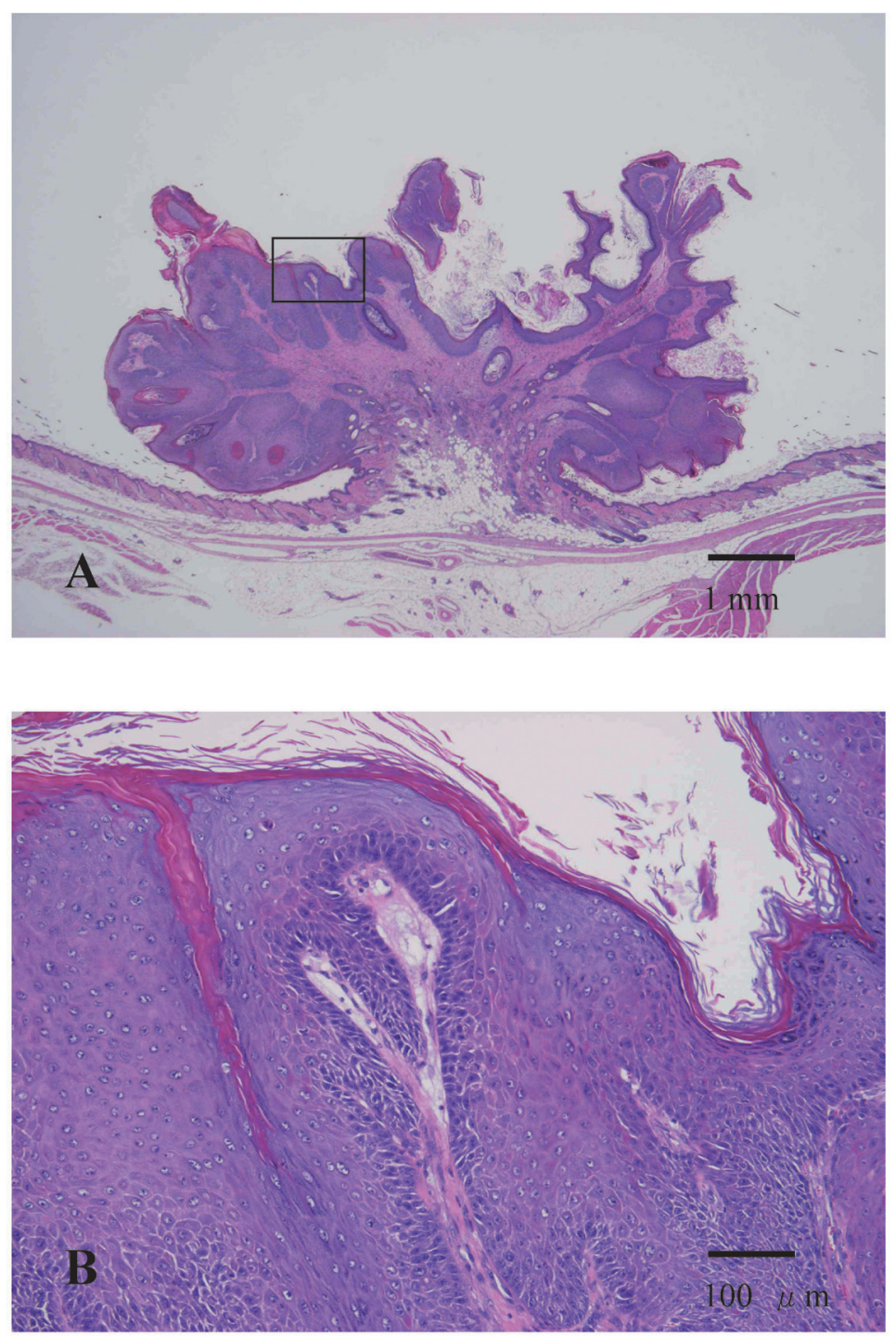

Fig. 3. Skin papilloma at the administration site of 12-o-tetradecanoylphorbol-13-acetate (TPA).

Photo B indicates magnification of enclosed area in Photo A, H.E. stain. 
from the untreated group were shown. Inflammatory cell infiltration, thickening of the epidermis and fibrosis were found at the hair loss sites around the Elizabeth collar in several mice in the Vaseline group, but no neoplastic changes were observed at this site (Table 1-2).

\section{DISCUSSION}

The ras $\mathrm{H} 2$ mouse is a genetically manipulated mouse transfected with the c-Ha-ras gene of human origin (Tamaoki, 2001), and it has been found to respond appropriately to both genotoxic and nongenotoxic carcinogens (Yamamoto et al., 1998; Usui et al., 2001). If percutaneous application is possible in this mouse model, it should become an extremely important tool for carcinogenicity tests in the non-clinical development of new medicines.

Predictably no tumor response rates in negative control mice are necessary for effective utilization of the model. At the same time, robust and predictable responses to positive control treatments are also essen- tial (Blanchard et al., 1998). In this study, it was clear from the lack of carcinogenesis in ras $\mathrm{H} 2$ mice at the sites of administration of the ethanol, white Vaseline and acetone, and the significant differences obtained in the incidence of dermal nodules between the TPA (positive control) group and untreated (negative control) group that the transgene might be involved in tumorigenesis. The tumorigenesis mechanism analysis should be performed in a parallel with a carcinogenicity test to confirm the relationship between transgene and induced tumor in the next study.

In Tg.AC mice approved by the FDA and CPMP as genetically manipulated mice for use in the shortterm carcinogenicity test for percutaneous administration (MacDonald et al., 2004), the incidence of skin tumors was $13 \%(2 / 15)$ (Spalding et al., 1999) and $6.2 \%(8 / 130)$ (Blanchard et al., 1998) for the vehicles such as ethanol and acetone. It is also well known that non-specific tumor responses to simulation such as trauma occur (Hansen et al., 1995; Weaver et al., 1998) and these mice are not considered as ideal animals for carcinogenicity tests. However, in this study, no tumor-

Table 1-1. Histopathological findings in $\mathrm{ras} \mathrm{H} 2$ mice.

\begin{tabular}{|c|c|c|c|c|c|c|c|c|c|c|c|}
\hline \multirow[b]{3}{*}{ Organ } & \multirow[b]{3}{*}{ Diagnosis/ total number } & \multicolumn{2}{|c|}{ Untreated } & \multicolumn{2}{|c|}{ Ethanol } & \multicolumn{2}{|c|}{ Vaseline } & \multicolumn{2}{|c|}{ Acetone } & \multicolumn{2}{|c|}{ TPA } \\
\hline & & male & female & male & female & male & female & male & female & male & female \\
\hline & & 15 & 14 & 14 & 14 & 15 & 15 & 13 & 15 & 14 & 15 \\
\hline \multirow[t]{4}{*}{ Skin (back area) ${ }^{1)}$} & Papilloma & 0 & 0 & 0 & 0 & 0 & 0 & 0 & 0 & 3 & $6^{*, 3)}$ \\
\hline & Keratoacanthoma & 0 & 0 & 0 & 0 & 0 & 0 & 0 & 0 & 0 & $3^{3)}$ \\
\hline & Squamous cell heperplasia & 0 & 0 & 0 & 0 & 0 & 0 & 0 & 0 & 3 & 2 \\
\hline & Parekeratosis & 0 & 0 & 0 & 0 & 0 & 0 & 0 & 0 & 0 & 1 \\
\hline \multirow[t]{3}{*}{ Skin $(\text { neck) })^{2)}$} & Inflammatory cell infiltration & 0 & 0 & $\mathrm{NE}$ & $\mathrm{NE}$ & 2 & $4 *$ & $\mathrm{NE}$ & $\mathrm{NE}$ & $\mathrm{NE}$ & $\mathrm{NE}$ \\
\hline & Thickening of epidermis & 0 & 0 & $\mathrm{NE}$ & $\mathrm{NE}$ & 0 & 1 & $\mathrm{NE}$ & $\mathrm{NE}$ & $\mathrm{NE}$ & $\mathrm{NE}$ \\
\hline & Fibrosis & 0 & 0 & $\mathrm{NE}$ & $\mathrm{NE}$ & 0 & $5^{*}$ & $\mathrm{NE}$ & $\mathrm{NE}$ & $\mathrm{NE}$ & $\mathrm{NE}$ \\
\hline Spleen & Hemangioma & 2 & 0 & 0 & 0 & 0 & 0 & 1 & 0 & 1 & 0 \\
\hline \multirow[t]{3}{*}{ Lungs } & Adenoma & 3 & 0 & 3 & 0 & 2 & 0 & 1 & 0 & 3 & 0 \\
\hline & Adenocarcinoma & 0 & 1 & 0 & 0 & 0 & 0 & 1 & 0 & 0 & 0 \\
\hline & Hemangioma & 0 & 1 & 0 & 0 & 0 & 0 & 0 & 0 & 0 & 0 \\
\hline \multirow[t]{3}{*}{ Liver } & Adenocarcinoma & 0 & 0 & 1 & 0 & 0 & 0 & 0 & 0 & 0 & 0 \\
\hline & Hepatoblastoma & 0 & 0 & 1 & 0 & 0 & 0 & 0 & 0 & 0 & 0 \\
\hline & Hemangioma & 0 & 0 & 0 & 0 & 1 & 0 & 0 & 0 & 0 & 0 \\
\hline Rectum & Hemangioma & 1 & 0 & 0 & 0 & 0 & 0 & 0 & 0 & 0 & 0 \\
\hline
\end{tabular}

\footnotetext{
*: Significant differences at $\mathrm{p}<0.05$ from untreated group (Fisher's exact test).

1): Correponds to administration area, ${ }^{2)}$ : Corresponds to attachment area of Elizabeth collar.

3): Both papilloma and keratoacanthoma were observed in two mice.

NE: not examined.
} 
Dermal application to $\mathrm{ras} \mathrm{H} 2$ mice.

igenic changes were observed at the site of contact with the Elizabeth collar for 26 weeks in ras $\mathrm{H} 2$ mice, indicating that no carcinogenetic action due to longterm physical irritation was observed.

From the above findings, it is clear that ras $\mathrm{H} 2$ mice showed different responses in the untreated (negative control), solvents (ethanol, Vaseline and acetone) and positive control groups so that bias in carcinogenicity assessment was very close to zero, suggesting that this mouse is appropriate for carcinogenicity assessment by percutaneous administration.

MNU (75 mg/kg, single intraperitoneal dose) is currently used as the positive control in ras $\mathrm{H} 2$ mice with $100 \%$ tumorigenicity (Yamamoto et al., 1998; Usui et al., 2001; Takaoka et al., 2003). However, with administration of TPA in this study, significant formation of skin papillomas was observed in female mice (in comparison with the negative control), but the incidence of tumors was $46.7 \%$ (7/15), which was about half of that in $\mathrm{Tg}$.AC mice [at least $90 \%$ in homozygotes, and $85-90 \%$ in heterozygotes (Eastin et al., 2001)]. The number of nodules in male and female ras $\mathrm{H} 2$ mice was 1.4 per mouse (range: $1-2)$ and 1.9 per mouse (range: 1-4), respectively, showing major differences from the results of $\mathrm{Tg}$.AC mice with at least 20 nodules per mouse (Eastin et al., 2001).
TPA is a promoter of skin carcinogenesis (Radman and Kinsella, 1980; Ohkawa et al., 1988), and when consideration is given to the properties of TPA and the stability of the transgene in ras $\mathrm{H} 2$ mice (only three copies introduced in a tandem array) (Tamaoki, 2001), some manipulations must be taken for the increase of incidence of skin papillomas and/or keratoacanthomas. It has been verified in Tg.AC mice that tumor incidence can be manipulated by changing the type of vehicle or the dose or administration frequency of TPA (Stoll et al., 2001; Weaver et al., 1998). Therefore, using these findings for reference, the increase in tumorigenicity caused by the positive control in $\operatorname{ras} \mathrm{H} 2$ mice is a topic for future study.

Furthermore, as the second step of this application study, 26-week carcinogenicity studies for not only mutagenic carcinogens such as 4-vinyl-1-cyclohexene diepoxide, but also for non-mutagenic carcinogens should be performed to add to the validation database.

Inhibition of body weight gain observed in males was not assumed to be a pathologically related finding but was caused by the effects of stress due to repeated drug administration or the Elizabeth collar.

Consequently, it was concluded that the percutaneous application to ras $\mathrm{H} 2$ mice is possible for $\mathrm{ras} \mathrm{H} 2$

Table 1-2. Histopathological findings in non-Tg mice.

\begin{tabular}{|c|c|c|c|c|c|c|c|c|c|c|c|}
\hline \multirow{3}{*}{ Organ } & \multirow[b]{3}{*}{ Diagnosis/ total number } & \multicolumn{2}{|c|}{ Untreated } & \multicolumn{2}{|c|}{ Ethanol } & \multicolumn{2}{|c|}{ Vaseline } & \multicolumn{2}{|c|}{ Acetone } & \multicolumn{2}{|c|}{ TPA } \\
\hline & & male & female & male & female & male & female & male & female & male & female \\
\hline & & 13 & 15 & 15 & 13 & 14 & 15 & 15 & 15 & 15 & 14 \\
\hline \multirow[t]{4}{*}{ Skin (back area) ${ }^{1)}$} & Papilloma & 0 & 0 & 0 & 0 & 0 & 0 & 0 & 0 & 0 & 0 \\
\hline & Keratoacanthoma & 0 & 0 & 0 & 0 & 0 & 0 & 0 & 0 & 0 & 0 \\
\hline & Squamous cell heperplasia & 0 & 0 & 0 & 0 & 0 & 0 & 0 & 0 & 1 & 2 \\
\hline & Parakeratosis & 1 & 0 & 0 & 0 & 0 & 0 & 0 & 0 & 0 & 0 \\
\hline \multirow[t]{3}{*}{ Skin $(\text { neck })^{2)}$} & Inflammatory cell infiltration & 0 & 1 & $\mathrm{NE}$ & $\mathrm{NE}$ & 1 & $6 *$ & $\mathrm{NE}$ & $\mathrm{NE}$ & $\mathrm{NE}$ & $\mathrm{NE}$ \\
\hline & Thickening of epidermis & 0 & 0 & $\mathrm{NE}$ & $\mathrm{NE}$ & 1 & 2 & $\mathrm{NE}$ & $\mathrm{NE}$ & $\mathrm{NE}$ & $\mathrm{NE}$ \\
\hline & Fibrosis & 0 & 0 & $\mathrm{NE}$ & $\mathrm{NE}$ & $8 * *$ & $7 * *$ & $\mathrm{NE}$ & $\mathrm{NE}$ & $\mathrm{NE}$ & $\mathrm{NE}$ \\
\hline Spleen & Hemangioma & 0 & 0 & 0 & 0 & 0 & 0 & 0 & 0 & 0 & 0 \\
\hline \multirow[t]{3}{*}{ Lungs } & Adenoma & 2 & 0 & 0 & 0 & 0 & 1 & 1 & 0 & 0 & 0 \\
\hline & Adenocarcinoma & 0 & 0 & 0 & 0 & 0 & 0 & 0 & 0 & 0 & 0 \\
\hline & Hemangioma & 0 & 0 & 0 & 0 & 0 & 0 & 0 & 0 & 0 & 0 \\
\hline \multirow[t]{3}{*}{ Liver } & Adenocarcinoma & 0 & 0 & 0 & 0 & 0 & 0 & 0 & 0 & 0 & 0 \\
\hline & Hepatoblastoma & 0 & 0 & 0 & 0 & 0 & 0 & 0 & 0 & 0 & 0 \\
\hline & Hemangioma & 0 & 0 & 0 & 0 & 0 & 0 & 0 & 0 & 0 & 0 \\
\hline Rectum & Hemangioma & 0 & 0 & 0 & 0 & 0 & 0 & 0 & 0 & 0 & 0 \\
\hline
\end{tabular}

* and **: Significant differences at $\mathrm{p}<0.05$ and $\mathrm{p}<0.01$ from untreated group, respectively (Fisher's exact test).

1): Correponds to administration area, ${ }^{2)}$ : Corresponds to attachment area of Elizabeth collar.

NE: not examined. 
mice of 26-week carcinogenicity tests.

\section{ACKNOWLEDGMENT}

The authors wish to express their gratitude to Masumi Yoshimura of the Central Institute for Experimental Animals, and to Eiko Nishinaka and Akiko Tanabe of JAC for their help in care and management of the animals and the carcinogenicity studies.

\section{REFERENCES}

Blanchard, K.T., Ball, D.J., Holden, H.E., Furst, S.M., Stoltz, J.H. and Stoll, R.E. (1998): Dermal carcinogenicity in transgenic mice: Relative responsiveness of male and female hemizygous and homozygous Tg.AC mice to 12-o-tetradecanoylphorbol 13-acetate (TPA) and Benzene. Toxicol. Pathol., 26, 541-547.

Cannon, R.E., Spalding, J. W., Trempus, C.S., Szczesniak, C.J., Virgil, K.M., Humble, M.C. and Tennant, R.W. (1997): Kinetics of woundinduced $\mathrm{v}-\mathrm{Ha}$-ras transgene expression and papilloma development in transgenic Tg.AC mice. Mol. Carcinog., 20, 108-114.

Eastin, W.C., Mennear, J.H., Tennant, R.W., Stoll, R.E., Branstetter, D.G., Bucher, J.R., McCullough, B., Binder, R.L., Spalding, J.W. and Mahler, J.F. (2001): Tg.AC genetically altered mouse: Assay working group overview of available data. Toxicol. Pathol., 29 (Suppl.), 60-80.

Hansen, L.A., Spalding, J.W., French, J.E. and Tennant, R.W. (1995): A transgenic mouse model (Tg.AC) for skin carcinogenesis: Inducible transgene expression as a second critical event. Prog. Clin. Biol. Res., 391, 223-235.

Honchel, R., Rosenzweig, B.A., Thompson, K.L., Blanchard, K.T., Furst, S.M., Stoll, R.E. and Sistare, F.D. (2001): Loss of palindromic symmetry in $\mathrm{Tg}$. AC mice with a nonresponder phenotype. Molecular Carcinogenesis, 30, 99-110.

Leder, A., Kuo, A., Cardiff, R.D., Sinn, E. and Leder, P. (1990): v-Ha-ras-transgene abrogates the initiation step in mouse skin tumorigenesis: Effects of phorbol esters and retinoic acid. Proc. Natl. Acad. Sci. USA, 87, 9178-9182.

MacDonald, J., French, J.E., Gerson, R.J., Goodman, J., Inoue, T., Jacobs, A., Kasper, P., Keller, D., Lavin, A., Long, G., McCullough, B., Sistare, F.D., Storer, R. and van der Laan, J.W. (2004):
The utility of genetically modified mouse assays for identifying human carcinogens: A basic understanding and path forward. Toxicol. Sci., 77, 188-194.

National Toxicology Program (1989): Toxicology and carcinogenesis studies of 4-vinyl-1- cyclohexene diepoxide (CAS No. 106-87-6) in F344/N rats and $\mathrm{B} 6 \mathrm{C} 3 \mathrm{~F} 1$ mice, NTP TR 362, NIH Publication No. 90-2817.

Ohkawa, Y., Iwata, K. and Inui, N. (1988): Screening for skin-tumor promoters. Biomed. Pharmacother., 42, 447-450.

Radman, M. and Kinsella, A.R. (1980): Chromosomal events in carcinogenic initiation and promotion: Implications for carcinogenicity testing and cancer prevention strategies. IARC Sci. Publ., 27, 75-90.

Spalding, J.W., French, J.E., Tice, R.R., FurediMachacek, M., Haseman, J.K. and Tennant, R.W. (1999): Development of a transgenic mouse model for carcinogenesis bioassays: Evaluation of chemically induced skin tumors in Tg.AC mice. Toxicol. Sci., 49. 241-254.

Stoll, R.E., Furst, S.M., Stoltz, J.H., Lilly, P.D. and Mennear, J.H. (2001): Dermal carcinogenicity in transgenic mice: Effect of vehicle on responsiveness of hemizygous Tg.AC mice to phorbol 12-myristate 13-acetate (TPA). Toxicol. Pathol., 29, 535-540.

Takaoka, M., Sehata, S., Maejima, T., Imai, T., Torii, M., Satoh, H., Toyosawa, K., Tanakamaru, Z., Adachi, T., Hisada, S., Ueda, M., Ogasawara, H., Matsumoto, M., Kobayashi, K., Mutai, M. and Usui, T. (2003): Interlaboratory camparison of short-term carcinogenicity studies using CB6F1-rasH2 transgenic mice. Toxicol. Pathol., 31, 191-199.

Tamaoki, N. (2001): The ras $\mathrm{H} 2$ transgenic mouse: Nature of the model and mechanistic studies on tumorigenesis. Toxicol. Pathol., 29 (Suppl.), 8189.

Thompson, K.L., Rosenzweig, B.A. and Sistare, F.D. (1998): An evaluation of the hemizygous transgenic Tg.AC mouse for carcinogenicity testing of pharmaceuticals. II. A genotypic marker that predicts tumorigenic responsiveness. Toxicol. Pathol., 26, 548-555.

Usui, T., Mutai, M., Hisada, S., Takaoka, M., Soper, K.E., McCullough, B. and Alden, C. (2001): CB6F1-ras $\mathrm{H} 2$ mouse: overview of available data. Toxicol. Pathol., 29 (Suppl.), 90-108. 
Dermal application to $\mathrm{ras} \mathrm{H} 2$ mice.

Weaver, J.L., Contrera, J.F., Rosenzweig, B.A., Thompson, K.L., Faustine, P.J., Strong, J.M., Ellison, C.D., Anderson, L.W., Prasanna, H.R., Long-Bradley, P.E., Lin, K.K., Zhang, J. and Sistare, F.D. (1998): An evaluation of the hemizygous transgenic Tg.AC mouse for carcinogenicity testing of pharmaceuticals. I. Evidence for a confounding nonresponder phenotype.
Toxicol. Pathol., 26, 532-540.

Yamamoto, S., Urano, K., Koizumi, H., Wakana, S., Hioki, K., Mitsumori, K., Kurokawa, Y., Hayashi, Y. and Nomura, T. (1998): Validation of transgenic mice carrying the human prototype c-Ha-ras gene as a bioassay model for carcinogenicity testing. Environment. Health Perspect., 106 (Supple. 1), 57-69. 